\title{
Eskimo Art in a Community College Library
}

\author{
BY BERNARD C. RINK
}

The Mark Osterlin LibraRY at Northwestern Michigan College has literally translated Ars gratia artis into an active program of presenting original art to its academic and civic communities. It all began when an enterprising Chicago executive donated a rare collection of Eskimo carvings to be sold for the benefit of the college library. The library, with the assistance of a committee of art-conscious citizens, then organized an Eskimo art exhibit and sale. The donated carvings were enhanced with stonecut and sealskin stencil prints from Cape Dorset, Baffin Island, Canada. Enough money was realized from the sale to subsidize a yearround art exhibit program in the library. In fact, the event was so successful that the Eskimo art exhibit and sale has now become an annual summer event. Furthermore, the Mark Osterlin library has become one of the few authorized outlets for Eskimo art in America.

The proceeds from the sale are placed' by the library in a separate account labeled "the Eskimo art fund." The benefits of this fund are manifold. The most gratifying service provided, of course, is a year-round program of original art exhibits in the library. A different art show is presented each month. The exhibitions shown have ranged from "African Sculpture," loaned by the Segy Gallery in New York, to "Painters of the Western World," from the permanent collection of the International Business Machines Corporation. Cost of rental, shipping, and insurance is covered by the Eskimo art fund.
Mr. Rink is Librarian of Northwestern Michigan College.

In addition to subsidizing the monthly exhibits, the funds derived from Eskimo art enable the library to buy original prints and paintings from them. This collection now includes fifteen carvings and forty prints and paintings. These, coupled with the modest but growing fine arts collection, represent the source for a program of circulating art works to the college faculty for home or office use. Eventually, the Mark Osterlin library hopes to assemble enough prints to sponsor a traveling Eskimo art exhibit at a moderate rental fee. Prior to receipt of the Eskimo art, the college had no art collection.

The purchase and sale of reproductions and post cards of the great masterpieces represents further service stemming from the Eskimo art fund. They are bought with fund money and sold to the students on a nonprofit basis. Consequently, any student can familiarize himself with the classic art works by tacking them up in his room. Since we began selling these reproductions in the library, we have noticed little or no mutilation of fine arts reproduction books.

This blueprint for presenting art to students and citizens represents only one way that a library can patronize the arts and enhance the cultural environment of its users. Much of its success originates in the excellence and popularity of Eskimo art-an art that is primitive yet sophisticated enough to captivate those who are exposed to it. 
Some librarians no doubt object to using library space to display and promote the fine arts. To them it represents an intrusion on the library "sanctum sanctorum." One must judge such projects, however, in their settings, where specific differences overrule general library beliefs or practices. First of all, Northwestern Michigan College is a two-year community college without a fine arts building, located in a small city that has no art gallery or museum. In such an area, devoid of an art gallery within several hundred miles, the display and sale of art objects in the library assumes a cogency that would not be justified in more culturally-endowed urban areas where facilities for the preservation and presentation of art already exist.

From an academic standpoint it also befits a community college library to patronize the arts if the opportunity arises and the space exists. One of the most pressing tasks of a two-year college is to provide its students with an educational and cultural experience that approximates that in a four-year college or university experience. Exposing the two-year student to at least a few of the cultural advantages

\section{Perspective ...}

(Continued from page 92)

such questions as these: (1) Do I take such care in my work that a minimum number of books are lost due to my typing errors, wrong labeling, or inaccurate cataloging? (2) Am I trying to keep the proper division of my time between socializing with my fellow workers and doing my job? Are too many books or periodicals not reaching the shelves because I have wasted my time? (3) Am I engaged in a systematic study program in order to improve my skills? that his four-year counterparts enjoy will certainly assist rather than shortchange him when he does transfer to a university where he will have to compete and associate with individuals who have lived and studied in richer cultural environments.

The effects of original art display are far from immediate or measurable in a setting that has never had such a program. We are convinced, however, that our humble beginning will accrue interest and eventually pay dividends-possibly a fine arts center at Northwestern Michigan College. At least, our hope is that Eskimo art proceeds will be parlayed into even greater benefits for our college and community during the next decade. A recent letter concerning our library exhibit series from August Heckscher, special consultant on the arts to the White House, states the challenge we are attempting to meet: "That such an undertaking should be carried on by a community college library is particularly interesting. The relationship of the college to the arts-and of the arts to the community-is a big opportunity which needs to be explored through just such initiatives as your own." 